\title{
A genome-wide association analysis for body, udder, and leg conformation traits recorded in Murciano-Granadina goats
}

\author{
Maria Gracia Luigi-Sierra, ${ }^{1} \odot$ Vincenzo Landi, ${ }^{2,3} \odot$ Dailu Guan, ${ }^{1} \odot$ Juan Vicente Delgado, ${ }^{2} \odot$ Anna Castelló, ${ }^{1,4} \odot$ \\ Betlem Cabrera, ${ }^{1,4}$ Emilio Mármol-Sánchez, ${ }^{1} \oplus$ Javier Fernández Alvarez, ${ }^{5} \odot$ Mayra Gómez-Carpio, ${ }^{2} \odot$ \\ Amparo Martínez, ${ }^{2}$ (i) Xavier Such, ${ }^{6}$ (D) Jordi Jordana, ${ }^{4}(\mathbb{C})$ and Marcel Amills ${ }^{1,4 *}$ (i) \\ ${ }^{1}$ Centre for Research in Agricultural Genomics (CRAG), CSIC-IRTA-UAB-UB, Campus Universitat Autònoma de Barcelona, Bellaterra 08193, \\ Spain \\ ${ }^{2}$ Departamento de Genética, Universidad de Córdoba, Córdoba 14071, Spain \\ ${ }^{3}$ Department of Veterinary Medicine, University of Bari "Aldo Moro," SP. 62 per Casamassima km. 3, 70010 Valenzano (BA), Italy \\ ${ }^{4}$ Departament de Ciència Animal i dels Aliments, Facultat de Veterinària, Universitat Autònoma de Barcelona, Bellaterra 08193, Spain \\ ${ }^{5}$ Asociación Nacional de Criadores de Caprino de Raza Murciano-Granadina (CAPRIGRAN), 18340 Granada, Spain \\ ${ }^{6}$ Group of Research in Ruminants (G2R), Department of Animal and Food Science, Universitat Autònoma de Barcelona (UAB), Bellaterra, \\ Barcelona 08193, Spain
}

\section{ABSTRACT}

Morphological traits are of great importance to dairy goat production given their effect on phenotypes of economic interest. However, their underlying genomic architecture has not yet been extensively characterized. Herein, we aimed to identify genomic regions associated with body, udder, and leg conformation traits recorded in 825 Murciano-Granadina goats. We genotyped this resource population using the GoatSNP50 BeadChip (Illumina Inc., San Diego, CA) and performed genomewide association analyses using the GEMMA software. We found 2 genome-wide significant associations between markers rs268273468 [Capra hircus (CHI) 16:69617700] and rs268249346 (CHI 28:18321523) and medial suspensory ligament. In contrast, we did not detect any genome-wide significant associations for body and leg traits. Moreover, we found 12, 19, and 7 chromosome-wide significant associations for udder, body, and leg traits, respectively. Comparison of our data with previous studies revealed a low level of positional concordance between regions associated with morphological traits. In addition to technical factors, this lack of concordance could be due to a substantial level of genetic heterogeneity among breeds or to the strong polygenic background of morphological traits, which makes it difficult to detect genetic factors that have small phenotypic effects.

Key words: genome-wide association study (GWAS), goat, Murciano-Granadina, morphological trait

Received March 2, 2020.

Accepted August 3, 2020.

*Corresponding author: marcel.amills@uab.cat

\section{INTRODUCTION}

Since its establishment in 1975 (Delgado et al., 2018), the Murciano-Granadina breed has become the most important dairy goat breed in Spain, reaching 112,417 heads in 2019 (https:/ /www.mapa.gob.es/es/ganaderia/ temas/zootecnia/razas-ganaderas/razas). MurcianoGranadina goats show great ability to adapt to harsh environments, yielding $530 \mathrm{~kg}$ of milk per lactation $(250 \mathrm{~d})$ with fat and protein contents of 5.6 and $3.6 \%$, respectively (https://www.mapa.gob.es/es/ganaderia/ temas/zootecnia/razas-ganaderas/razas). The genetic improvement program of the Murciano-Granadina breed is mostly focused on increasing milk yield and quality and on optimizing body and dairy conformation traits. The association of Murciano-Granadina breeders (Caprigran) systematically records information about milk yield and composition and performs linear scoring of 17 morphological traits (Delgado et al., 2018). The inclusion of morphological traits as selection criteria is motivated by their association with mammary health and longevity (Shelton, 1978; Manfredi et al., 2001; Montaldo and Manfredi, 2002). Studies performed in cattle (Seykora and McDaniel, 1985; Rogers et al., 1991; Boettcher et al., 1998; Rupp and Boichard, 1999; Miglior et al., 2017) support a relationship between udder morphology and health. Indeed, higher, nonpendulous, and more tightly attached udders are less susceptible to mastitis (Seykora and McDaniel, 1985; Rupp and Boichard, 2003). Moreover, flat, disk, or inverted teat ends are associated with an increased risk of suffering mastitis, whereas funnel-shaped teats seem to be less prone to mastitis (Seykora and McDaniel, 1985). Numerous reports associate body traits with fertility and longevity (Bastin and Gengler 2013; Miglior et al., 2017). For instance, foot and leg conformation traits 
could be considered indicators of claw health, which, after reproduction and mastitis, is one of the main determinants for culling animals (Egger-Danner et al., 2015).

Few studies about the genetics of morphological traits have been performed in goats. According to Rupp et al. (2011), udder floor position showed negative genetic correlations $\left(\mathbf{r}_{\mathrm{g}}\right)$ with SCS in both Alpine $\left(\mathrm{r}_{\mathrm{g}}=-0.24\right)$ and Saanen goats $\left(r_{g}=-0.19\right)$. The same authors demonstrated that, in the Saanen breed, SCS was correlated with teat length $\left(\mathrm{r}_{\mathrm{g}}=0.29\right)$, teat width $(\mathrm{rg}=$ $0.34)$, and teat form $\left(r_{g}=-0.27\right)$. These results suggest that a reduction in SCC could be achieved by selection, while still improving milk production and udder type and teat traits. In Tinerfeña goats, moderate to high and mostly positive phenotypic correlations have been detected between udder traits and milk yield (Capote et al., 2006).

Manfredi et al. (2001) found a high heritability $\left(\mathrm{h}^{2}>\right.$ 0.4) for thorax perimeter in Alpine and Saanen goats, whereas other body traits such as rump angle, feet angle, and hock distance showed low heritabilities $\left(\mathrm{h}^{2}\right.$ $=0.03-0.16)$. In contrast, heritabilities for udder and teat scores were around 0.3 for most traits, with teat angle displaying the lowest value $\left(\mathrm{h}^{2}=0.15\right.$ in Saanen). Genetic correlations among teat dimension traits and between udder floor and rear udder attachment $\left(\mathrm{r}_{\mathrm{g}}>\right.$ 0.7 in Alpine and Saanen) were generally high, whereas the majority of genetic correlations between body and udder scores were $<0.3$ (Manfredi et al., 2001).

In a more recent study, McLaren et al. (2016) described low to moderate heritabilities (from 0.02 to 0.38) for conformation traits recorded in mixed-breed dairy goats: although udder and teat traits had the highest heritabilities $\left(\mathrm{h}^{2} \sim 0.28\right.$, from 0.15 to 0.38$)$, feet and leg traits showed lower values $\left(\mathrm{h}^{2} \sim 0.13\right.$, from 0.02 to 0.25 ). Although most of the correlations estimated between milk yield and udder and teat traits were negative, their magnitude and sign fluctuated across the first lactation. For instance, estimates of the genetic correlation between udder furrow and milk yield ranged from -0.42 to 0.18 depending on the time point in first lactation when they were calculated (McLaren et al., 2016). Castañeda-Bustos et al. (2017) described a high genetic correlation between the productive life of dairy goats (i.e., total days in production until 72 mo of age) and final score (appraisal of the general conformation of the animal), fore udder attachment, and rump width. These findings demonstrate that considering conformation and udder traits in selection schemes would be expected to increase productivity without compromising the fitness of the animals (Castañeda-Bustos et al., 2017).
Several investigations have been carried out to identify genomic regions associated with body conformation and udder traits in goats. Mucha et al. (2018) performed a GWAS for morphology traits in mixed-breed dairy goats and found a significant association between a region on chromosome 19 and udder attachment, udder depth, and front leg morphology. Moreover, Martin et al. (2018) detected 37 genome-wide significant QTL for type and SCS phenotypes with linkage analyses, whereas a much larger number of QTL were identified by association mapping. These authors concluded that the inheritance of body and udder conformation traits is markedly polygenic and that genetic determinants are often breed-specific. In the current work, we aimed to identify genomic regions associated with the phenotypic variation of 17 morphological traits in MurcianoGranadina goats.

\section{MATERIALS AND METHODS}

\section{Phenotypic Recording}

A total of 825 female goats distributed in 13 farms, with an average herd size of 500 individuals, were scored for 17 morphological traits included in the breeding program of the Murciano-Granadina goat breed. The scoring is performed only once in the lifetime of the animal. Most of the goats in our study were scored during their first lactation, although a group of 89 animals was scored between the second and sixth lactations. All traits were scored by the same specialist, using a personal digital device equipped with the Kalifadroid app (Fernández Alvarez, 2017) for carrying out scoring tasks. The following phenotypes were evaluated, with linear scores ranging from 1 to 9 according to the criteria established in Sánchez-Rodríguez (2012).

\section{Udder Traits}

Seven udder traits were scored:

- Fore udder attachment (FUA) - Corresponds to the angle formed by the line of the udder insertion and the abdominal wall. Scores 1 and 9 correspond to angles of $45^{\circ}$ and $120^{\circ}$, respectively.

- Rear udder height (RUH) - Scored by measuring the distance between the bottom of the vulva and the top of the secretory tissue of the mammary gland. Scores 1 and 9 correspond to distances of 11 and $3 \mathrm{~cm}$, respectively.

- Udder depth (UD)-Distance from the lowest part of the udder floor to the hock joint (tibiotarsal joint). A linear score of 1 corresponds to an 
udder with its deepest part $10 \mathrm{~cm}$ over the hock, whereas a score of 9 would define an udder with its deepest part $10 \mathrm{~cm}$ down the hock joint.

- Medial suspensory ligament (MSL) -Depth of the udder cleft measured at the base of the rear udder. Scores 1 and 9 correspond to 1 and $9 \mathrm{~cm}$ (or more) deep udder clefts, respectively.

- Udder width (UW)-Measured at the crease where the udder meets the leg. Scores of 1 and 9 correspond to measurements of 3 and $11 \mathrm{~cm}$ (or more), respectively.

- Teat diameter (TD)-Diameter of the teat at its base, when it meets the udder. The measurement was performed for each teat individually and the average score was used as final score. Score $1=$ diameter of $0.5 \mathrm{~cm}$ and score $9=$ diameter of 4.5 $\mathrm{cm}$ or more.

- Teat placement (TP)-Defines the position of the teats on the udder half. Teats located on the outside third of the udder half are scored as 1, whereas teats located very close to the medial suspensory ligament, that almost touch each other, are scored as 9. The measurement was performed for each teat individually and the average score was used as final score. Teats on the center of the udder half, with an intermediate placement, are considered desirable and are scored as 5 .

\section{Body Conformation Traits}

Seven body conformation traits were scored:

- Height (HT) - Measures the distance from ground level to the top of the withers. Goats with a height of $62 \mathrm{~cm}$ or less received a score of 1 , and those over $78 \mathrm{~cm}$ received a score of 9 .

- Chest width (CW)-Measured from the inside surface of the chest between the top of the front legs. Score $1=15 \mathrm{~cm}$ or less; score $9=23 \mathrm{~cm}$ or more.

- Body depth (BD) - Distance between the top of the spine and bottom of the body at the beginning of the last rib. Score 1 = low depth, if the beginning of the last rib is located above the elbow joint, and score $9=$ high depth, if the beginning of the last rib is located below the elbow joint.

- Rump width (RW) -Distance between the most posterior points of the pin bones (ischial tuberosities). Score $1=13 \mathrm{~cm}$ (or less); score $9=21 \mathrm{~cm}$ (or more).

- Rump angle (RA)-Angle between the hook (coxal tuberosity) and pin (ischial tuberosity) bones. Scores 1 and 9 correspond to angles of approximately $55^{\circ}$ and $31^{\circ}$, respectively.
- Angularity or dairyness (ANG)-Angle and openness of the ribs. Score 1 defines an animal extremely coarse for this trait; score 9 is assigned to goats that are very angular.

- Bone quality (BQ)-Appraisal of the thickness and width of the bone structure, assessed by examining the rear leg from the rear and from the side. Score 1 corresponds to goats with thick and round bones; score 9 is assigned to goats with flat and sharp bones.

\section{Feet Structure}

Three feet structure traits were scored:

- Rear legs rear view (RLR) - Direction of rear feet when viewed from the rear. Score 1: extreme toeout feet; score 9: parallel feet.

- Rear legs side view (RLS) - Curvature of the hock viewed laterally. Score 1: straight legs; score 9: very curved legs.

- Mobility (MOB) - Evaluates the locomotion patterns, including the length and direction of the step. Score 1: bad locomotion, with severe abduction and short steps; score 9: harmonic, long and uniform locomotion.

\section{Isolation of Genomic DNA from Blood and Genotyping with the Goat SNP50 BeadChip}

Blood samples from the 825 Murciano-Granadina goats with morphology records were collected in vacuum tubes coated with $\mathrm{K}_{3}$-EDTA anticoagulant and stored at $-20^{\circ} \mathrm{C}$ until processing. Genomic DNA was purified using a modified salting-out procedure (Miller et al., 1988). In brief, we combined $3 \mathrm{~mL}$ of whole blood plus 4 volumes of Red Cell Lysis Solution (10 m $M$ Tris$\mathrm{HCl}, \mathrm{pH}$ 6.5; 2 mM EDTA; $1 \%$ Tween 20) and then this mixture was centrifuged at $2,000 \times g$ for $2 \mathrm{~min}$. The resulting cell pellet was resuspended in $3 \mathrm{~mL}$ of lysis buffer (200 mM Tris-HCl, pH 8, $30 \mathrm{~m} M$ EDTA, $1 \% \mathrm{SDS}, 250 \mathrm{mM} \mathrm{NaCl}$ ) and $100 \mu \mathrm{L}$ of proteinase $\mathrm{K}$ $(20 \mathrm{mg} / \mathrm{mL})$ and incubated for $3 \mathrm{~h}$ at $55^{\circ} \mathrm{C}$. The lysate was chilled, and $1 \mathrm{~mL}$ of $10 \mathrm{M}$ ammonium acetate was added. This mixture was centrifuged at 2,000 $\times g$ for 10 min, and the supernatant $(\sim 4 \mathrm{~mL})$ was transferred to a new tube with $3 \mathrm{~mL}$ of $96 \%$ isopropanol. Subsequently, samples were centrifuged at $2,000 \times g$ for $3 \mathrm{~min}$. The resulting DNA pellet was washed with $3 \mathrm{~mL}$ of ethanol $70 \%$ followed by an additional centrifugation step at $2,000 \times g$ for $1 \mathrm{~min}$. The DNA pellet was left at room temperature until it dried, and then was resuspended in $1 \mathrm{~mL}$ of Tris-EDTA buffer $(10 \mathrm{~m} M$ Tris-HCl, $1 \mathrm{~m} M$ EDTA, $\mathrm{pH}=8)$. All 825 goats were genotyped with 
the Illumina Goat SNP50 BeadChip (Illumina Inc., San Diego, CA), which contains 54,241 SNP, following the instructions of the manufacturer. The genomic location of the SNPs was obtained using the goat ARS1 genome (Bickhart et al., 2017) as reference, and the position and the name of each SNP was updated using the software PLINK v 1.9 (Chang et al., 2015). The genotypic information was filtered using PLINK v 1.9 (Chang et al., 2015). Only individuals with $<5 \%$ missing genotypes were taken into consideration. With regard to SNPs, only those meeting the following requirements were used in the GWAS: (1) mapping to autosomes, (2) displaying a minor allele frequency of $\geq 0.05$, (3) not deviating very significantly $(P>0.001)$ from Hardy-Weinberg expectation, and (4) with a genotype call rate $>90 \%$. After applying these filtering criteria, 47,880 SNPs and 811 animals were selected to perform subsequent analyses. Population structure was assessed with a principal component analysis (PCA) implemented in PLINK v 1.9 (Chang et al., 2015). The visualization of the PCA results was based on the first 2 components of the PCA.

\section{Statistical Analyses}

We calculated summary statistics for each of the morphological traits using R (R Core Team, 2017) as well as Pearson correlations $\left(\mathbf{r}_{\mathbf{p}}\right)$ between conformation traits and milk composition and yield records; that is, total milk yield, milk yield at $210 \mathrm{~d}$, milk yield at 240 $\mathrm{d}$, milk yield at $305 \mathrm{~d}$, SCS, fat percentage, protein percentage, and lactose percentage. The correlations were estimated and heatmap plots constructed with $\mathrm{R}$ software (R Core Team, 2017) to visualize the correlation matrix and the $P$-values of each correlation.

The software GEMMA (Zhou and Stephens, 2012) was used to carry out the GWAS. This method corrects population structure by taking into account the relatedness matrix, which is built by considering all genomewide SNPs as a random effect. Morphological phenotypes were rank-based transformed using the package GenAbel from R (Aulchenko et al., 2007) because we assessed, with our data, that this transformation yields residuals that are normally distributed. A univariate linear mixed model was fit for each trait as follows:

$$
\mathbf{y}=\mathbf{W} \boldsymbol{\alpha}+\mathbf{x} \beta+\mathbf{u}+\varepsilon,
$$

where $\mathbf{y}$ is a vector of corrected scores for morphological traits recorded in 811 individuals; $\mathbf{W}=(\mathrm{w} 1, \ldots, \mathrm{wc})$ is an $n \times c$ matrix of 3 fixed effects (farm, with 13 levels; year of birth, with 10 levels; number of lactations, with 6 levels) and 1 covariate (days producing milk); $\boldsymbol{\alpha}$ is a $c$-vector of the corresponding fixed effects including the intercept; $\mathbf{x}$ is a $n$-vector of marker genotypes; $\beta$ is the effect size of the marker (allele substitution effect); $\mathbf{u}$ is a $n$-vector of random individual genetic effects with a normal distribution $\mathbf{u} \sim N\left(0, \lambda \tau^{-1} \mathbf{K}\right)$, where $\tau^{-1}$ is the variance of the residual error, $\lambda$ is the ratio between the 2 variance components, and $\mathbf{K}$ is the relatedness matrix derived from SNP genotypes. Finally, $\varepsilon$ is a $n$-vector of errors.

A false discovery rate (FDR) approach was applied to correct for multiple testing, setting the significance level to a $q$-value of 0.05 (Benjamini and Hochberg, 1995). Graphical visualization of the results of the GWAS was achieved by using the $\mathrm{R}$ software (R Core Team, 2017).

The proportion of the phenotypic variance explained by the significant SNPs (PVE) was estimated using the formula reported by Shim et al. (2015):

$$
\mathrm{PVE}=\frac{2 \hat{\beta}^{2} M A F(1-M A F)}{2 \hat{\beta}^{2} M A F(1-M A F)+[s e(\hat{\beta})]^{2} 2 N M A F(1-M A F)},
$$

where $\beta$ is the effect size of the SNP variant estimated from the association analysis; $M A F$ is the minor allele frequency of the SNP, se is the standard error, and $N$ is the sample size. Lambda inflation factors were calculated with the median method (1 df) implemented in GenABEL (Aulchenko et al., 2007), whereas quantilequantile (Q-Q) plots were built with the gg_qqplot() function (https://www.rdocumentation.org/packages/ lindia/versions/0.9/topics/gg_qqplot).

To retrieve candidate genes mapping close to significant SNP, we considered an interval of $\pm 1 \mathrm{Mb}$ based on data previously reported by Guan et al. (2020) for the same population. Genes mapping within these defined boundaries were listed by using the Biomart tool from Ensembl (Kinsella et al., 2011) and subsequently analyzed with Uniprot (UniProt Consortium, 2019) and David Bioinformatic Resources (Huang et al., 2009) to annotate their function.

\section{RESULTS AND DISCUSSION}

\section{Population Structure and Analysis of Morphological Traits}

The first 2 components ( $\mathrm{C} 1$ and $\mathrm{C} 2$ ) of the principal component analysis accounted for $42.64 \%$ and $21.76 \%$ of the genetic variance, respectively (Supplemental Figure S1; https://doi.org/10.3168/jds.2020-18461). Several samples were grouped according to their farm of origin, but we did not find an obvious within-population sub- 
structure in this sample of Murciano-Granadina goats. Descriptive statistics of the raw conformation scores are reported in Supplemental Table S1 and Supplemental Figures S2 and S3 (https://doi.org/10.3168/jds .2020-18461). The estimated phenotypic correlations and their significances are depicted in Supplemental Table S2 (https://doi.org/10.3168/jds.2020-18461) and Figure 1. We classified phenotypic correlations as low $\left(\mathrm{r}_{\mathrm{p}}<0.2\right)$, moderate $\left(\mathrm{r}_{\mathrm{p}}=0.2-0.4\right)$, or high $\left(\mathrm{r}_{\mathrm{p}}>\right.$ 0.4). Phenotypic correlations between udder traits were generally low and positive, except for the correlation between MSL and UD that was moderate $\left(\mathrm{r}_{\mathrm{p}}=0.37, P\right.$ $<0.001)$. In the study of McLaren et al. (2016), genetic correlations between udder traits ranged from 0.12 to 0.77 , whereas those between teat traits were in the range of -0.10 to 0.69 . Udder and teat traits were positively correlated, a result coincident with our findings, and also with those reported by Manfredi et al. (2001). We found low and positive correlations between SCS and MSL $\left(\mathrm{r}_{\mathrm{p}}=0.14, P<0.001\right)$, UD $\left(\mathrm{r}_{\mathrm{p}}=0.19, P<0.001\right)$, and TD $\left(\mathrm{r}_{\mathrm{p}}=0.13, P<0.001\right)$. Udder depth $\left(\mathrm{r}_{\mathrm{g}}=0.10\right)$ and teat size $\left(\mathrm{r}_{\mathrm{g}}=0.29\right)$ also showed positive genetic correlations with SCS in Latxa sheep (Legarra and Ugarte, 2005). Pendulous udders are closer to the floor, exposing the mammary gland to direct contact with fecal and other environmental contaminants (Pugh and Baird, 2012). Moreover, teat diameter is highly correlated with the diameter of the internal cistern (Guarín et al., 2017), and it is expected that teat sphincters in animals with wider cisterns do not close completely, leaving a channel open for pathogens, thus increasing the risk of suffering mastitis (Seykora and McDaniel, 1985). In contrast, UW $\left(\mathrm{r}_{\mathrm{p}}=-0.11, P<0.001\right)$ and TP $\left(\mathrm{r}_{\mathrm{p}}=-0.13, P<0.001\right)$ were negatively correlated with SCS, but these 2 values were low, and these 2 traits in other studies do not show strong genetic correlations with SCS (Legarra and Ugarte, 2005; Pérez-Cabal et al., 2013). Notably, UW $\left(\mathrm{r}_{\mathrm{p}}=0.20-0.21, P<0.001\right)$ and UD $\left(\mathrm{r}_{\mathrm{p}}=0.29-0.32, P<0.001\right)$ showed moderate positive correlations with milk yield. Pérez-Cabal et al. (2013) found moderate to high and positive phenotypic correlations between milk yield and udder width $\left(\mathrm{r}_{\mathrm{p}}\right.$ $=0.29)$ and udder depth $\left(\mathrm{r}_{\mathrm{p}}=0.47\right)$ in Spanish Assaf sheep, and Legarra and Ugarte (2005) reported a strong positive genetic correlation between milk yield and udder depth $\left(r_{g}=0.43\right)$. It is reasonable to infer that goats with wider and deeper udders produce more milk.

Phenotypic correlations between body conformation traits were generally high and positive. For instance, HT was correlated with $\mathrm{CW}\left(\mathrm{r}_{\mathrm{p}}=0.65, P<0.001\right)$, RW $\left(\mathrm{r}_{\mathrm{p}}=0.67, P<0.001\right)$, and ANG $\left(\mathrm{r}_{\mathrm{p}}=0.42, P<\right.$ $0.001)$; and $\mathrm{CW}$ showed positive correlations with $\mathrm{BD}$ $\left(\mathrm{r}_{\mathrm{p}}=0.41, P<0.001\right)$, RW $\left(\mathrm{r}_{\mathrm{p}}=0.74, P<0.001\right)$, and ANG $\left(\mathrm{r}_{\mathrm{p}}=0.68, P<0.001\right)$. Zujovic et al. $(2011)$ also observed high phenotypic correlations between body traits measured in Balkan goats, and Chacón et

A

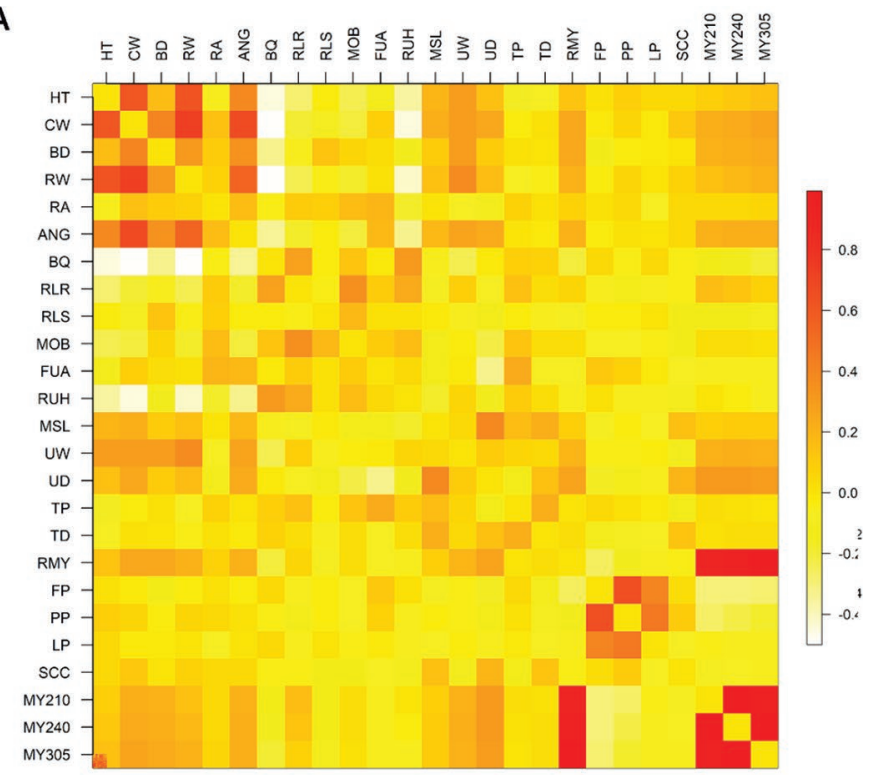

B

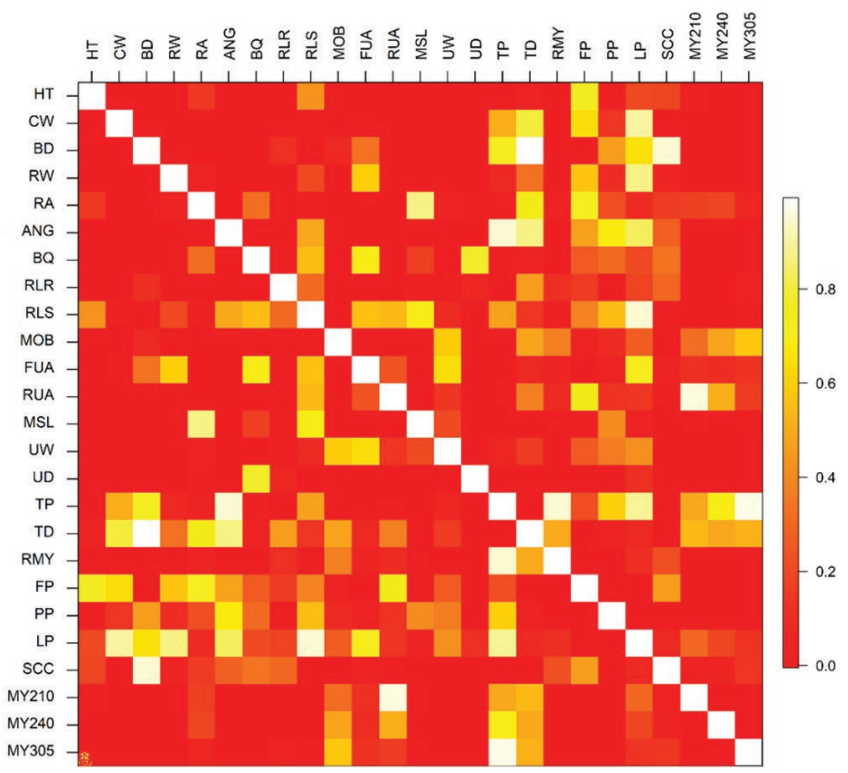

Figure 1. (A) Heatmap depicting Pearson correlations between morphological and milk yield phenotypes recorded in 811 MurcianoGranadina goats. The intensity of the color indicates the magnitude of the correlation. (B) Heatmap displaying the significance of the Pearson correlations shown in panel A. The intensity of the color indicates the significance of the association. Traits: HT, height; CW, chest width; BD, body depth; RW, rump width; RA, rump angle; ANG, angularity; BQ, bone quality; RLR, rear legs rear view; RLS, rear legs side view; MOB, mobility; FUA, fore udder attachment; RUH, rear udder height; MSL, medial suspensory ligament; UW, udder width; UD, udder depth; TP, teat placement; TD, teat diameter; RMY, total milk yield; MY210, milk yield corrected at 210 d of milking; MY240, milk yield corrected at $240 \mathrm{~d}$ of milking; MY305, milk yield corrected at $305 \mathrm{~d}$ of milking. 
al. (2011) observed a similar trend in Cuban goats. In general, taller goats are also bigger and have a wider chest and rump. We observed moderate positive correlations between $\mathrm{CW}$ and $\mathrm{BD}$ and milk yield $\left(\mathrm{r}_{\mathrm{p}}=\right.$ $0.2-0.3, P<0.001$ ) and between RW and milk yield $\left(\mathrm{r}_{\mathrm{p}}=0.15-0.2, P<0.001\right)$. In cows, individuals with a wider rump and increased space across their hooks and pins are reported to accommodate a higher and wider udder (Campbell and Marshall, 2016). These results suggest that the increase in udder capacity leads to a higher milk yield while decreasing the percentages of solid milk components ( $\%$ lactose, $\%$ fat, and $\%$ protein). There are also indications that cows with a short and round body often lack dairy character and udder capacity (Campbell and Marshall, 2016), supporting the positive correlation between ANG and milk yield observed in our Murciano-Granadina population.

With regard to leg traits, MOB displayed a positive phenotypic correlation with RLR $\left(\mathrm{r}_{\mathrm{p}}=0.42, P<0.001\right)$ and RLS $\left(\mathrm{r}_{\mathrm{p}}=0.23, P<0.001\right)$. Interestingly, RLR and RLS showed low positive and low negative correlations with milk yield, respectively. McLaren et al. (2016) observed a correlation of 0.33 between back legs and milk yield at $305 \mathrm{~d}$, whereas de la Fuente et al. (2011) estimated a small genetic correlation of -0.09 between the back legs and milk yield in Churra ewes.
Our interpretation is that leg morphology could be associated with the predisposition of goats to lameness, a pathology that results in decreased milk production and often in the culling of the affected animal (Archer et al., 2010).

\section{Identification of Genetic Determinants for Udder Traits}

After performing the GWAS, we detected 2 genomewide significant associations for the trait MSL (Table 1 and Figures 2A and 2B). We also found chromosomewide associations for the traits MSL (2 SNP), UW (1 SNP), UD (3 SNP), TP (4 SNP), and TD (2 SNP), as shown in Table 1 and Supplemental Figures S4 (Manhattan plots) and S5 (Q-Q plots; https://doi.org/10 .3168/jds.2020-18461). No significant SNP was found for FUA or RUH.

The rs268273468 (CHI 16: 69617700) marker, which was significantly associated with MSL at the genomewide level of significance (Table 1 and Figure 2), is located less than $1 \mathrm{Mb}$ from the lysophosphatidylglycerol acyltransferase 1 (LPGAT1) gene (Supplemental Table S3; https://doi.org/10.3168/jds.2020-18461). This gene encodes an enzyme involved in conversion of lysophosphatidylglycerol into phosphatidylglycerol,

Table 1. Genome-wide and chromosome-wide significant associations between SNPs and udder traits (MSL, medial suspensory ligament; TD, teat diameter; TP, teat placement; UD, udder depth; UW, udder width) recorded in 811 Murciano-Granadina goats

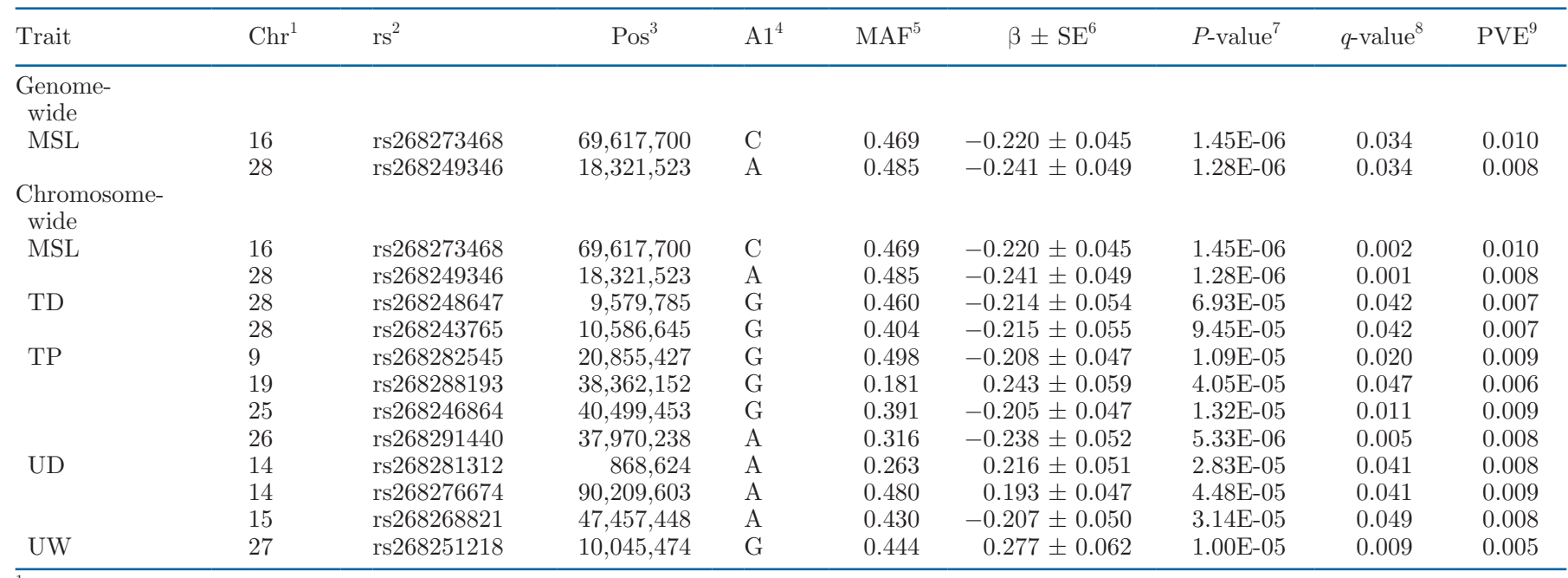

\footnotetext{
${ }^{1} \mathrm{Chr}$, chromosome.

${ }^{2}$ Identifier code of the SNP according to the Ensembl database (http://www.ensembl.org/).

${ }^{3}$ Position in base pairs.

${ }^{4}$ Minority allele.

${ }^{5}$ Minor allele frequency.

${ }^{6}$ Allelic substitution effect \pm SE.

${ }^{7}$ Raw $P$-values.

${ }^{8} P$-values corrected for multiple testing using a false discovery rate approach.

${ }^{9}$ Proportion of variance in phenotype explained by a given SNP.
} 
a membrane phospholipid that is a key precursor in the biosynthesis of cardiolipin (Yang et al., 2004). Interestingly, cardiolipin is located in the inner mitochondrial membrane and plays a fundamental role in maintaining mitochondrial membrane stability and dynamics as well as in regulating apoptosis (Paradies et al., 2014). Proper mitochondrial function, in turn, is essential to ensure the integrity of tendons and other connective tissues (Lowes et al., 2009; Thankam et al., 2018). With regard to rs268249346 (CHI 28: 18321523), the other genome-wide significant SNP for MSL, we found that it maps close to the ADAM metallopeptidase with thrombospondin type 1 motif 14 (ADAMTS14) locus (Supplemental Table S3). This gene has been reported to encode a procollagen $\mathrm{N}$-proteinase that cleaves the amino-propeptide of procollagen to allow the assembly of elongated and cylindrical collagen fibrils (Bekhouche and Colige, 2015), although one recent study indicates that the main role of this molecule is the regulation of the immune response (Dupont et al., 2018).
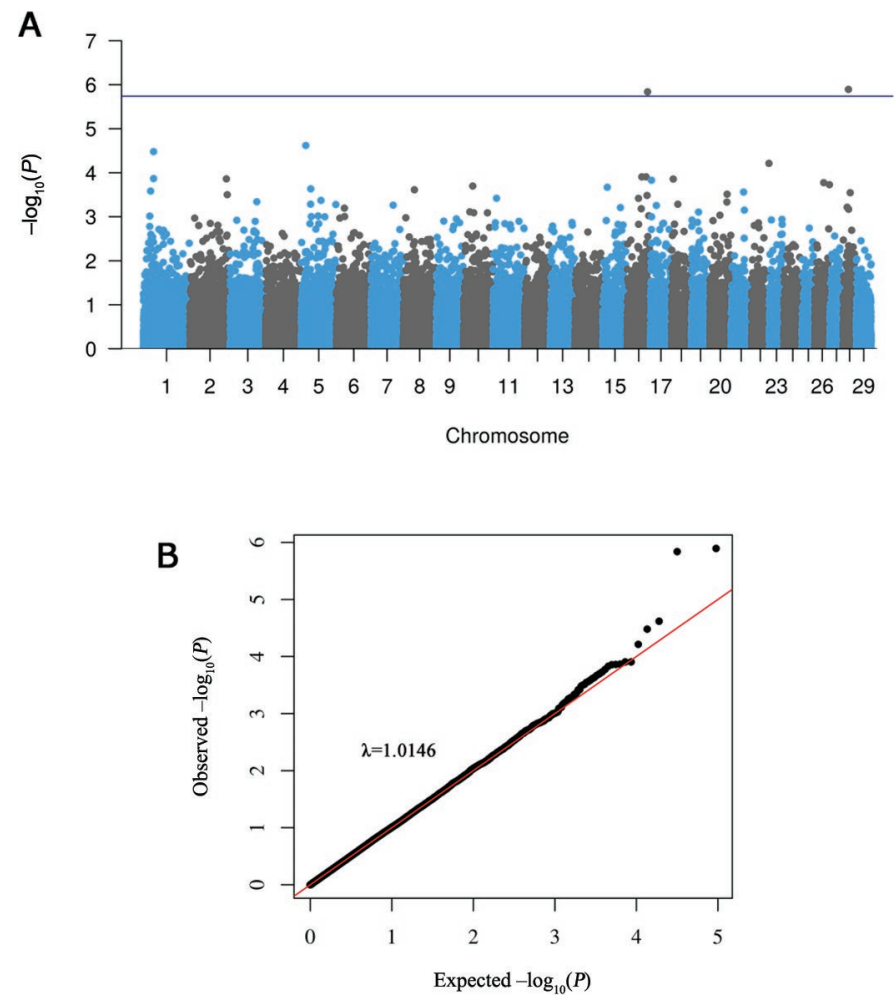

Figure 2. (A) Negative $\log _{10} P$-values ( $y$-axis) of the associations between SNPs and the medial suspensory ligament phenotype are plotted against the genomic location of each SNP marker ( $x$-axis). Markers on different chromosomes are denoted by different colors. The blue line indicates the $-\log _{10}(P$-value $)$ equivalent to a $q$-value of 0.05 . (B) Quantile-quantile plot corresponding to the genome-wide corrected $P$-values of the genome-wide association study for the trait medial suspensory ligament and its lambda $(\lambda)$ inflation factor.
We identified 12 SNP showing significant associations with udder traits at the chromosome-wide level (Table 1, Supplemental Figures S4 and S5). The activating transcription factor 3 (ATF3) gene is located close to the SNP rs268273468 (CHI 16: 69617700) associated with MSL (Supplemental Table S3). Interestingly, this gene modulates the synthesis of collagen I and III (Zhou et al., 2011) and regulates matrix metalloproteinases, which are fundamental in the development, renewal, and remodeling of tendons (Guenzle et al., 2017). Another interesting association is that between the rs268288193 marker (CHI 19: 38362152) and TP. The region containing this SNP was associated with SCS in Saanen goats (Martin et al., 2018). Of note, Lund et al. (1994) reported that cows with bad teat placement tend to be more susceptible to mastitis. Less than $1 \mathrm{Mb}$ from this SNP, we identified the suppressor of cytokine signaling 7 (SOCS 7 ) gene (Supplemental Table S3), which inhibits prolactin, growth hormone, and leptin signaling (Martens et al., 2005). Members of this gene family are regulators of mammary gland physiology. For instance, in mice, SOCS1 and SOCS2 attenuate prolactin signaling, thus preventing premature lactation (Sutherland et al., 2007). In dairy sheep, a missense polymorphism (R96C) in SOCS2 is associated with mastitis susceptibility, while having a positive effect on milk production and BW (Rupp et al., 2015). This antagonistic relationship could be due to co-selection of alleles influencing milk yield and susceptibility to mastitis, due to a hitchhiking effect, or to pleiotropy (Oget et al., 2019). Moreover, SOCS3 is a key regulator of mammary gland involution (Sutherland et al., 2007). In dairy cattle, polymorphisms in $S O C S 7$ have been associated with different milk traits such as protein yield and percentage and milk yield (Arun et al., 2015).

The collagen type XIV $\alpha_{1}$ chain $(C O L 14 A 1)$ gene is located 0.1 Mb away from rs268281312 (CHI 14:868624), which was significantly associated with UD (Supplemental Table S3). This gene encodes a fibril-associated collagen that regulates fibrillogenesis (Lindholm et al., 2019). In the human mammary gland, large amounts of type XIV collagen have been found in interlobular stroma, which, compared with intralobular stroma, contains densely packed collagen (Atherton et al., 1998). This differential distribution of type XIV collagen might have an important effect on the architecture of the mammary connective tissue.

\section{Identification of Genetic Determinants for Body Conformation Traits}

Although we did not detect any genome-wide significant associations for body conformation traits, we found 19 SNPs at the chromosome-wide level signifi- 
Table 2. Chromosome-wide significant associations between SNPs and body traits (ANG, angularity; BD, body depth; BQ, bone quality; CW, chest width; HT, height; RA, rump angle; RW, rump width) recorded in 811 Murciano-Granadina goats

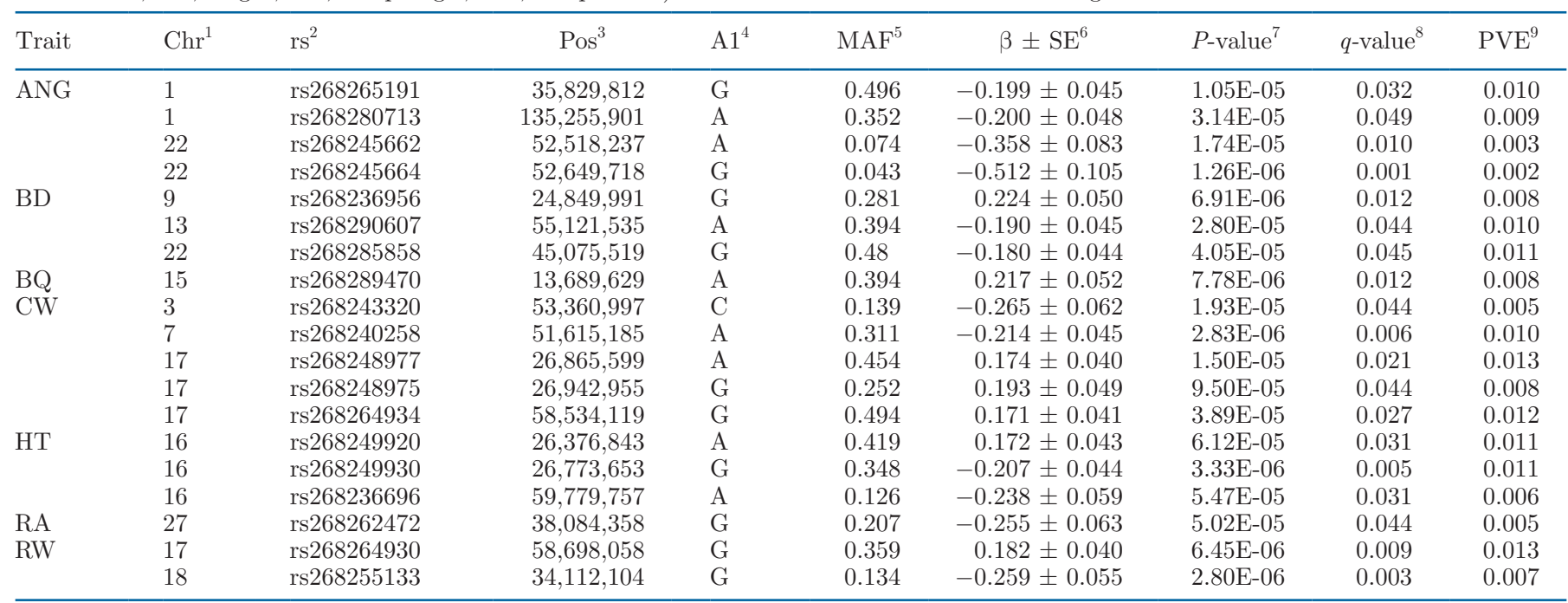

\footnotetext{
${ }^{1} \mathrm{Chr}$, chromosome.

${ }^{2}$ Identifier code of the SNP according to the Ensembl database (http://www.ensembl.org/).

${ }^{3}$ Position in base pairs.

${ }^{4}$ Minority allele.

${ }^{5}$ Minor allele frequency.

${ }^{6}$ Allelic substitution effect \pm SE.

${ }^{7}$ Raw $P$-values.

${ }^{8} P$-values corrected for multiple testing using a false discovery rate approach.

${ }^{9}$ Proportion of variance in phenotype explained by a given SNP.
}

cantly associated with ANG (4 SNP), RW (2 SNPs), RA (1 SNP), CW (5 SNP), HT (3 SNP), BD (3 SNP), and BQ (1 SNP). These results are displayed in Table 2 and in Supplemental Figures S6 (Manhattan plots) and S7 (Q-Q plots; https://doi.org/10.3168/jds.2020 -18461).

Several of the aforementioned SNP map close to genes involved in bone homeostasis and skeletal development (Supplemental Table S3). For instance, rs268245664, which is associated with ANG, maps to the parathyroid hormone 1 receptor (PTH1R) locus (Table 2, and Supplemental Table S3). This gene encodes a protein that acts as a receptor for parathyroid hormone (PTH) and parathyroid-related peptide (PTHrP), 2 factors regulating mineral ion homeostasis (Mannstadt et al., 1999). The dysfunction of $P T H 1 R$ is associated with diseases that affect skeletal development and calcium homeostasis (Mannstadt et al., 1999). With regard to the association between ANG and rs268265191 (CHI 1: 35829812$)$, it is worth mentioning that this marker maps near to the ephrin receptor A3 gene (EPHA3; Supplemental Table S3). Ephrin receptors and their associated ligands are essential modulators of bone remodeling and they ensure adequate coupling between bone resorption and formation (Edwards and Mundy,
2008). Interestingly, the inactivation of the ephrin-B1 gene causes perinatal lethality, abdominal wall closure defects, and skeletal abnormalities, especially of the thoracic cage (Compagni et al., 2003). Another interesting gene is that encoding the CGG triplet repeat binding protein 1 (CGGBP1), which is located $1 \mathrm{Mb}$ from rs268265191 (CHI 1: 35829812; Supplemental Table S3). Polymorphisms in this gene are associated with several carcass traits in cattle (Calonge, 2004), having considerable effects on growth (Sevane et al., 2014). Moreover, Sevane et al. (2014) described a nonsynonymous mutation, rs477676137 (c.206A > G, 1: 36060631 ), in $C G G B P 1$ associated with an increase in pelvis width and withers height measured at 9 mo. In contrast, rs268255133 (CHI 18: 34112104), which was associated with RW, maps close to the cadherin 11 gene (CDH11; Supplemental Table S3), which modulates postnatal bone growth and osteoblast differentiation (Di Benedetto et al., 2010). Furthermore, rs268262472 (CHI 27: 38084358), which is associated with RA, lies near the spermatogenesis-associated 4 gene (SPATA4), which is also involved in promoting osteoblast differentiation (Wang et al., 2011).

Another marker of interest is rs268285858 (CHI 22: 45075519). This SNP was associated with BD and is 
Table 3. Chromosome-wide significant associations between SNPs and leg traits (MOB, mobility; RLR, rear legs rear view; RLS, rear legs side view) recorded in 811 Murciano-Granadina goats

\begin{tabular}{|c|c|c|c|c|c|c|c|c|c|}
\hline Trait & $\mathrm{Chr}^{1}$ & $\mathrm{rs}^{2}$ & $\mathrm{Pos}^{3}$ & $\mathrm{~A} 1^{4}$ & $\mathrm{MAF}^{5}$ & $\beta \pm \mathrm{SE}^{6}$ & $P$-value ${ }^{7}$ & $q$-value ${ }^{8}$ & $\mathrm{PVE}^{9}$ \\
\hline \multirow[t]{2}{*}{ RLR } & 17 & rs268258221 & $21,284,278$ & G & 0.367 & $-0.255 \pm 0.061$ & $2.98 \mathrm{E}-05$ & 0.041 & 0.006 \\
\hline & 24 & rs268286224 & $42,536,581$ & $\mathrm{~A}$ & 0.117 & $-0.376 \pm 0.092$ & $4.26 \mathrm{E}-05$ & 0.027 & 0.002 \\
\hline \multirow[t]{2}{*}{ RLS } & 3 & rs268254620 & $8,818,355$ & G & 0.356 & $-0.188 \pm 0.046$ & $4.41 \mathrm{E}-05$ & 0.050 & 0.010 \\
\hline & 3 & rs268285963 & $43,496,497$ & $\mathrm{~A}$ & 0.3 & $0.211 \pm 0.048$ & $1.20 \mathrm{E}-05$ & 0.027 & 0.009 \\
\hline
\end{tabular}

${ }^{1} \mathrm{Chr}=$ chromosome.

${ }^{2}$ Identifier code of the SNP according to the Ensembl database (http://www.ensembl.org/).

${ }^{3}$ Position in base pairs.

${ }^{4}$ Minority allele.

${ }^{5}$ Minor allele frequency.

${ }^{6}$ Allelic substitution effect \pm SE.

${ }^{7}$ Raw $P$-values.

${ }^{8} P$-values corrected for multiple testing using a false discovery rate approach.

${ }^{9}$ Proportion of variance in phenotype explained by a given SNP.

located close to the Wnt family member 5A (WNT5A) gene (Supplemental Table S3) that regulates planar cell polarity signaling during embryonic development (Qian et al., 2007). Loss of this gene results in a shortened and widened cochlea in knockout mice embryos and severe shortening of the anterior-posterior axis and limb truncations due to abnormal convergent extension (Yamaguchi et al., 1999; Qian et al., 2007; Andre et al., 2015). Finally, rs268249930 (CHI 16: 26773653), which is associated with HT, co-localizes with DNAH14 (Supplemental Table S3), which encodes an axonemal dynein heavy chain. Mutations in dynein genes can cause skeletal ciliopathies characterized by thoracic narrowing, short long bones, and pelvis dysplasia (Yildiz, 2018).

\section{Identification of Genetic Determinants for Leg Structure Traits}

No genome-wide significant SNP was found for leg structure traits, but 7 SNP showed significant associations at the chromosome-wide level. These findings are reported in Table 3 as well as in Supplemental Figures S8 (Manhattan plot) and S9 (Q-Q plot; https://doi.org/ 10.3168/jds.2020-18461). For the MOB trait, an association was found with rs268236663 (CHI 2:16211260), located $600 \mathrm{~kb}$ from the endothelin converting enzyme like 1 (ECEL1) gene (Supplemental Table S3), which encodes an endopeptidase member of the M13 family involved in the regulation of neuropeptide and peptide hormone activity. This molecule has an important function in the development of the neuromuscular junctions of the limbs in mice (Nagata et al., 2016). Mice lacking this gene display poor arborization of the neuromo- tor nerves and a significant reduction of the number of neuromuscular junctions (Nagata et al., 2016). In humans, digital arthrogryposis is caused by mutations in ECEL1, and affected individuals show limited flexion of the knee and fingers as well as muscular atrophy (Dieterich et al., 2013).

Another interesting association was that between RLR and rs268286224 (CHI 24:42536581), which is positioned near the gene encoding piezo type mechanosensitive ion channel component 2 (PIEZO2; Supplemental Table S3), which is also involved in the etiology of digital arthrogryposis (Delle Vedove et al., 2016). Homozygous individuals for mutations inactivating PIEZO2 suffer from arthrogryposis and scoliosis (Haliloglu et al., 2017), while carriers of gain-of-function mutations can present multiple congenital contractures of limbs and variable absence of cruciate knee ligaments, among other symptoms (Coste et al., 2013).

\section{The Genomic Architecture of Morphological Traits}

Comparing our results with those obtained by Martin et al. (2018) and Mucha et al. (2018), we can state that there is a general lack of positional coincidence between the genomic regions associated with conformation traits in the aforementioned studies. Furthermore, in the study of Martin et al. (2018), different regions were identified in the Alpine and Saanen breeds as being associated with body phenotypes, suggesting that this lack of concordance is not the result of technical factors. Indeed, we found only 2 SNP displaying genome-wide significant associations with morphological traits. Such limited results are probably due to the fact that inheritance of morphological traits in goats 
is highly polygenic, with many genetic variants having small effects determining phenotypic variation. In other words, the success of GWAS largely depends on the genomic architecture of the trait rather than on the magnitude of its heritability. Stature is a good example of this because it is a highly heritable and, at the same time, a highly polygenic trait. In cattle, 163 genomic regions associated with stature have been detected but they explain only $13.8 \%$ of the phenotypic variance (Bouwman et al., 2018). Similarly, in humans, at least 180 genetic markers mostly segregating in populations of European descent explain $\sim 10 \%$ of the variance in height, a phenotype that has high heritability close to $\sim 0.8$ (Yang et al., 2010). This remarkable gap between genealogical heritability and the percentage of the phenotypic variance explained by the SNPs is caused, at least in part, by the existence of hundreds or thousands of genetic determinants with small phenotypic effects on stature. Similar reasoning can probably be made for the majority of body, leg, and udder morphological traits, because with the population sizes often used in bovine, ovine or caprine GWAS, the number of significant hits is generally very low (Schmid and Bennewitz, 2017).

Currently, we do not know whether the lack of positional concordance between GWAS for morphology traits recorded in goats is due to the existence of a substantial genetic heterogeneity across populations or to the modest size of the populations used in GWAS, a circumstance that limits our ability to detect variants with small effects that explain the majority of the phenotypic variance of morphological traits. Indeed, large GWAS performed in humans have demonstrated that many of the genetic variants that are associated with height are shared between individuals of European and African descent (N'Diaye et al., 2011), reinforcing the idea that the magnitude of genetic heterogeneity between populations is greatly reduced when large sample sizes are used in GWAS.

\section{CONCLUSIONS}

The number of hits detected in our GWAS for body conformation, udder, and leg traits was quite limited, a result that agrees well with previous studies. This outcome probably reflects the highly polygenic nature of morphological traits in ruminants. In comparing our results with previous reports, we also detected low positional concordance. This could be the consequence of genetic heterogeneity in the genetic determinism of morphological traits or because the GWAS carried out to date are underpowered to reliably detect the genetic determinants of such phenotypes. Despite these limitations, we identified several genes related to collagen synthesis (ATF3, ADAMTS14, and COL14A1), growth (CGGBP1), development (WNT5A and DNAH14), bone homeostasis and remodeling (PTH1R, CDH11, SPATA4, and EPHA3), limb development (ECEL1 and PIEZO2), and mammary physiology (SOCS 7 ) mapping close to GWAS hits. Such information, combined with candidate gene sets generated in other GWAS, if possible with much larger reference populations, could provide valuable clues about the identity of the loci shaping the body, udder, and leg morphology of goats.

\section{ACKNOWLEDGMENTS}

The authors are indebted to the Asociación Nacional de Criadores de Caprino de Raza Murciano-Granadina (Caprigran) for their cooperation in this study, specifically to Miguel García García and Teresa Novo Díaz, who collected all blood samples, and to Antonio Martín Ramírez who recorded all linear score measurements. This research was funded by the European Fund for Regional Development/Ministerio de Ciencia, Innovación y Universidades - Agencia Estatal de Investigación/ Project Reference (AGL2016-76108-R). We acknowledge the financial support from the Spanish Ministry of Economy and Competitiveness, through the "Severo Ochoa Programme for Centres of Excellence in R\&D" 2016-2019 (SEV-2015-0533), and from the CERCA programme of the Generalitat de Catalunya. Emilio Mármol-Sánchez was funded with an FPU PhD grant awarded by the Spanish Ministry of Education (FPU15/01733). Maria Gracia Luigi-Sierra was funded with an FPI PhD grant from the Spanish Ministry of Economy and Competitivity (BES-2017-079709). The authors have not stated any conflicts of interest.

\section{REFERENCES}

Andre, P., H. Song, W. Kim, A. Kispert, and Y. Yang. 2015. WNT5A and WNT11 regulate mammalian anterior-posterior axis elongation. Development 142:1516-1527. https://doi.org/10.1242/dev .119065 .

Archer, S. C., M. J. Green, and J. N. Huxley. 2010. Association between milk yield and serial locomotion score assessments in UK dairy cows. J. Dairy Sci. 93:4045-4053. https://doi.org/10.3168/ jds.2010-3062.

Arun, S. J., P. C. Thomson, P. A. Sheehy, M. S. Khatkar, H. W. Raadsma, and P. Williamson. 2015. Targeted analysis reveals an important role of JAK-STAT-SOCS genes for milk production traits in Australian dairy cattle. Front. Genet. 6:342. https://doi .org/10.3389/fgene.2015.00342.

Atherton, A. J., M. J. Warburton, M. J. O'Hare, P. Monaghan, D. Schuppan, and B. A. Gusterson. 1998. Differential expression of type XIV collagen/undulin by human mammary gland intralobular and interlobular fibroblasts. Cell Tissue Res. 291:507-511. https://doi.org/10.1007/s004410051020.

Aulchenko, Y. S., S. Ripke, A. Isaacs, and C. M. van Duijn. 2007. GenABEL: An R library for genome-wide association analysis. Bioinformatics 23:1294-1296. https://doi.org/10.1093/bioinformatics/ btm108. 
Bastin, C., and N. Gengler. 2013. Genetics of body condition score as an indicator of dairy cattle fertility: A review. Biotechnol. Agron. Soc. Environ. 17:64-75.

Bekhouche, M., and A. Colige. 2015. The procollagen N-proteinases ADAMTS2, 3 and 14 in pathophysiology. Matrix Biol. 44-46:4653. https://doi.org/10.1016/j.matbio.2015.04.001.

Benjamini, Y., and Y. Hochberg. 1995. Controlling the false discovery rate-A practical and powerful approach to multiple testing. J. R. Stat. Soc. B 57:289-300. https://doi.org/10.1111/j.2517-6161 .1995.tb02031.x.

Bickhart, D. M., B. D. Rosen, S. Koren, B. L. Sayre, A. R. Hastie, S. Chan, J. Lee, E. T. Lam, I. Liachko, S. T. Sullivan, J. N. Burton, H. J. Huson, J. C. Nystrom, C. M. Kelley, J. L. Hutchison, Y. Zhou, J. Sun, A. Crisà, F. A. Ponce De León, J. C. Schwartz, J. A. Hammond, G. C. Waldbieser, S. G. Schroeder, G. E. Liu, M. J. Dunham, J. Shendure, T. S. Sonstegard, A. M. Phillippy, C. P. Van Tassell, and T. P. L. Smith. 2017. Single-molecule sequencing and chromatin conformation capture enable de novo reference assembly of the domestic goat genome. Nat. Genet. 49:643-650. https://doi.org/10.1038/ng.3802.

Boettcher, P. J., J. C. M. Dekkers, and B. W. Kolstad. 1998. Development of an udder health index for sire selection based on somatic cell score, udder conformation, and milking speed. J. Dairy Sci. 81:1157-1168. https://doi.org/10.3168/jds.S0022-0302(98)75678 -4 .

Bouwman, A. C., H. D. Daetwyler, A. J. Chamberlain, C. H. Ponce, M. Sargolzaei, F. S. Schenkel, G. Sahana, A. Govignon-Gion, S. Boitard, M. Dolezal, H. Pausch, R. F. Brøndum, P. J. Bowman, B. Thomsen, B. Guldbrandtsen, M. S. Lund, B. Servin, D. J. Garrick, J. Reecy, J. Vilkki, A. Bagnato, M. Wang, J. L. Hoff, R. D. Schnabel, J. F. Taylor, A. A. E. Vinkhuyzen, F. Panitz, C. Bendixen, L. E. Holm, B. Gredler, C. Hozé, M. Boussaha, M. P. Sanchez, D. Rocha, A. Capitan, T. Tribout, A. Barbat, P. Croiseau, C. Drögemüller, V. Jagannathan, C. Vander Jagt, J. J. Crowley, A. Bieber, D. C. Purfield, D. P. Berry, R. Emmerling, K. U. Götz, M. Frischknecht, I. Russ, J. Sölkner, C. P. Van Tassell, R. Fries, P. Stothard, R. F. Veerkamp, D. Boichard, M. E. Goddard, and B. J. Hayes. 2018. Meta-analysis of genome-wide association studies for cattle stature identifies common genes that regulate body size in mammals. Nat. Genet. 50:362-367. https://doi.org/10.1038/ s41588-018-0056-5.

Calonge, M. E. 2004. Identificación de genes con expresión diferencial en tejido muscular de bovinos pertenecientes a los tres genotipos de la miostatina (mutación nt821(del11)). PhD Thesis. Universidad Complutense de Madrid, Spain.

Campbell, J. R., and R. T. Marshall. 2016. Dairy Production and Processing: The Science of Milk and Milk Products. 1st ed. Waveland Press Inc., Long Grove, IL.

Capote, J., A. Argüello, N. Castro, J. L. López, and G. Caja. 2006. Short communication: Correlations between udder morphology, milk yield, and milking ability with different milking frequencies in dairy goats. J. Dairy Sci. 89:2076-2079. https://doi.org/10.3168/ jds.S0022-0302(06)72276-7.

Castañeda-Bustos, V. J., H. H. Montaldo, M. Valencia-Posadas, L. Shepard, S. Pérez-Elizalde, O. Hernández-Mendo, and G. TorresHernández. 2017. Linear and nonlinear genetic relationships between type traits and productive life in US dairy goats. J. Dairy Sci. 100:1232-1245. https://doi.org/10.3168/jds.2016-11313.

Chacón, E., F. Macedo, F. Velázquez, S. R. Paiva, E. Pineda, and C. McManus. 2011. Morphological measurements and body indices for Cuban Creole goats and their crossbreds. Rev. Bras. Zootec. 40:1671. https://doi.org/10.1590/S1516-35982011000800007.

Chang, C. C., C. C. Chow, L. C. A. M. Tellier, S. Vattikuti, S. M. Purcell, and J. J. Lee. 2015. Second-generation PLINK: rising to the challenge of larger and richer datasets. Gigascience 4:7. https: //doi.org/10.1186/s13742-015-0047-8.

Compagni, A., M. Logan, R. Klein, and R. H. Adams. 2003. Control of skeletal patterning by EphrinB1-EphB interactions. Dev. Cell 5:217-230. https://doi.org/10.1016/S1534-5807(03)00198-9.

Coste, B., G. Houge, M. F. Murray, N. Stitziel, M. Bandell, M. A. Giovanni, A. Philippakis, A. Hoischen, G. Riemer, U. Steen, V.
M. Steen, J. Mathur, J. Cox, M. Lebo, H. Rehm, S. T. Weiss, J. N. Wood, R. L. Maas, S. R. Sunyaev, and A. Patapoutian. 2013. Gain-of-function mutations in the mechanically activated ion channel PIEZO2 cause a subtype of distal arthrogryposis. Proc. Natl. Acad. Sci. USA 110:4667-4672. https://doi.org/10.1073/ pnas. 1221400110.

de la Fuente, L. F., C. Gonzalo, J. P. Sánchez, R. Rodríguez, J. A. Carriedo, and F. S. Primitivo. 2011. Genetic parameters of the linear body conformation traits and genetic correlations with udder traits, milk yield and composition, and somatic cell count in dairy ewes. Can. J. Anim. Sci. 91:585-591. https://doi.org/10.4141/ cjas2010-031.

Delgado, J. V., V. Landi, C. J. Barba, J. Fernández, M. M. Gómez, M. E. Camacho, M. A. Martínez, F. J. Navas, and J. M. León. 2018. Murciano-Granadina goat: A Spanish local breed ready for the challenges of the twenty-first century. Pages 205-219 in Sustainable Goat Production in Adverse Environments. Vol. 2. J. Simões and C. Gutiérrez, ed. Springer International Publishing, Heidelberg, Germany.

Delle Vedove, A., M. Storbeck, R. Heller, I. Hölker, M. Hebbar, A. Shukla, O. Magnusson, S. Cirak, K. M. Girisha, M. O'Driscoll, B. Loeys, and B. Wirth. 2016. Biallelic loss of proprioceptionrelated PIEZO2 causes muscular atrophy with perinatal respiratory distress, arthrogryposis, and scoliosis. Am. J. Hum. Genet. 99:1206-1216. https://doi.org/10.1016/j.ajhg.2016.09.019.

Di Benedetto, A., M. Watkins, S. Grimston, V. Salazar, C. Donsante, G. Mbalaviele, G. L. Radice, and R. Civitelli. 2010. N-cadherin and cadherin 11 modulate postnatal bone growth and osteoblast differentiation by distinct mechanisms. J. Cell Sci. 123:2640-2648. https://doi.org/10.1242/jcs.067777.

Dieterich, K., S. Quijano-Roy, N. Monnier, J. Zhou, J. Fauré, D. A. Smirnow, R. Carlier, C. Laroche, P. Marcorelles, S. Mercier, A Mégarbané, S. Odent, N. Romero, D. Sternberg, I. Marty, B. Estournet, P. S. Jouk, J. Melki, and J. Lunardi. 2013. The neuronal endopeptidase ECEL1 is associated with a distinct form of recessive distal arthrogryposis. Hum. Mol. Genet. 22:1483-1492. https: //doi.org/10.1093/hmg/dds514.

Dupont, L., G. Ehx, M. Chantry, C. Monseur, C. Leduc, L. Janssen, D. Cataldo, M. Thiry, C. Jerome, J. M. Thomassin, B. Nusgens, J. Dubail, F. Baron, and A. Colige. 2018. Spontaneous atopic dermatitis due to immune dysregulation in mice lacking ADAMTS2 and 14. Matrix Biol. 70:140-157. https://doi.org/10.1016/j.matbio .2018.04.002.

Edwards, C. M., and G. R. Mundy. 2008. Eph receptors and ephrin signaling pathways: A role in bone homeostasis. Int. J. Med. Sci. 5:263-272. https://doi.org/10.7150/ijms.5.263.

Egger-Danner, C., J. B. Cole, J. E. Pryce, N. Gengler, B. Heringstad, A. Bradley, and K. F. Stock. 2015. Invited review: Overview of new traits and phenotyping strategies in dairy cattle with a focus on functional traits. Animal 9:191-207. https://doi.org/10.1017/ S1751731114002614.

Fernández Álvarez, J. 2017. Herramientas Informáticas para el Control y Gestión de Rebaños: Eskardillo, Kalifa, Inteka y Siamelk. VIII Foro Nacional del Caprino, Carmona (Sevilla), Spain. https: //www.cabrandalucia.com/inicio/foro-nacional-caprino/viii-foro -nacional-del-caprino/.

Guan, D., V. Landi, M. G. Luigi-Sierra, J. V. Delgado, X. Such, A. Castelló, B. Cabrera, E. Mármol-Sánchez, J. Fernández-Alvarez, J. L. R. de la Torre Casañas, A. Martínez, J. Jordana, and M. Amills. 2020. Analyzing the genomic and transcriptomic architecture of milk traits in Murciano-Granadina goats. J. Anim. Sci. Biotechnol. 11:35. https://doi.org/10.1186/s40104-020-00435-4.

Guarín, J. F., M. G. Paixão, and P. L. Ruegg. 2017. Association of anatomical characteristics of teats with quarter-level somatic cell count. J. Dairy Sci. 100:643-652. https://doi.org/10.3168/jds.2016 -11459 .

Guenzle, J., L. J. Wolf, N. W. C. Garrelfs, J. M. Goeldner, N. Osterberg, C. R. Schindler, J. E. Saavedra, and A. Weyerbrock. 2017. $A T F 3$ reduces migration capacity by regulation of matrix metalloproteinases via $N F \kappa B$ and $S T A T 3$ inhibition in glioblastoma. Cell 
Death Discov. 3:17006. https://doi.org/10.1038/cddiscovery.2017 .6.

Haliloglu, G., K. Becker, C. Temucin, B. Talim, N. Küçüksąhin, M. Pergande, S. Motameny, P. Nürnberg, U. Aydingoz, H. Topaloglu, and S. Cirak. 2017. Recessive PIEZO2 stop mutation causes distal arthrogryposis with distal muscle weakness, scoliosis and proprioception defects. J. Hum. Genet. 62:497-501. https://doi.org/10 $.1038 /$ jhg.2016.153.

Huang, W., B. T. Sherman, and R. A. Lempicki. 2009. Systematic and integrative analysis of large gene lists using DAVID bioinformatics resources. Nat. Protoc. 4:44-57. https://doi.org/10.1038/nprot .2008 .211 .

Kinsella, R. J., A. Kähäri, S. Haider, J. Zamora, G. Proctor, G. Spudich, J. Almeida-King, D. Staines, P. Derwent, A. Kerhornou, P. Kersey, and P. Flicek. 2011. Ensembl BioMarts: A hub for data retrieval across taxonomic space. Database (Oxford) 2011:bar030. https://doi.org/10.1093/database/bar030.

Legarra, A., and E. Ugarte. 2005. Genetic parameters of udder traits, somatic cell score, and milk yield in Latxa sheep. J. Dairy Sci. 88:2238-2245. https://doi.org/10.3168/jds.S0022-0302(05)72899 $-\mathrm{X}$.

Lindholm, M., T. Manon-Jensen, and M. A. Karsdal. 2019. Type XIV collagen. Pages 121-125 in Biochemistry of Collagens, Laminins and Elastin. Vol. 2. M. A. Karsdal, ed. Academic Press, London, UK.

Lowes, D. A., C. Wallace, M. P. Murphy, N. R. Webster, and H. F. Galley. 2009. The mitochondria targeted antioxidant MitoQ protects against fluoroquinolone-induced oxidative stress and mitochondrial membrane damage in human achilles tendon cells. Free Radic. Res. 43:323-328. https://doi.org/10.1080/10715760902736275.

Lund, T., F. Miglior, J. C. M. Dekkers, and E. B. Burnside. 1994. Genetic relationships between clinical mastitis, somatic cell count, and udder conformation in Danish Holsteins. Livest. Prod. Sci. 39:243-251. https://doi.org/10.1016/0301-6226(94)90203-8.

Manfredi, E., A. Piacere, P. Lahaye, and V. Ducrocq. 2001. Genetic parameters of type appraisal in Saanen and Alpine goats. Livest. Prod. Sci. 70:183-189. https://doi.org/10.1016/S0301 -6226(01)00180-4.

Mannstadt, M., H. Jüppner, and T. J. Gardella. 1999. Receptors for PTH and PTHrP: Their biological importance and functional properties. Am. J. Physiol. 277:F665-F675. https://doi.org/10 .1152/ajprenal.1999.277.5.F665.

Martens, N., G. Uzan, M. Wery, R. Hooghe, E. L. Hooghe-Peters, and A. Gertler. 2005. Suppressor of cytokine signaling 7 inhibits prolactin, growth hormone, and leptin signaling by interacting with STAT5 or STAT3 and attenuating their nuclear translocation. J. Biol. Chem. 280:13817-13823. https://doi.org/10.1074/jbc M411596200.

Martin, P., I. Palhière, C. Maroteau, V. Clément, I. David, G. T. Klopp, and R. Rupp. 2018. Genome-wide association mapping for type and mammary health traits in French dairy goats identifies a pleiotropic region on chromosome 19 in the Saanen breed. J. Dairy Sci. 101:5214-5226. https://doi.org/10.3168/jds.2017-13625.

McLaren, A., S. Mucha, R. Mrode, M. Coffey, and J. Conington. 2016. Genetic parameters of linear conformation type traits and their relationship with milk yield throughout lactation in mixed-breed dairy goats. J. Dairy Sci. 99:5516-5525. https://doi.org/10.3168/ jds.2015-10269.

Miglior, F., A. Fleming, F. Malchiodi, L. F. Brito, P. Martin, and C. F. Baes. 2017. A 100-Year review: Identification and genetic selection of economically important traits in dairy cattle. J. Dairy Sci. 100:10251-10271. https://doi.org/10.3168/jds.2017-12968.

Miller, S. A., D. D. Dykes, and H. F. Polesky. 1988. A simple salting out procedure for extracting DNA from human nucleated cells. Nucleic Acids Res. 16:1215. https://doi.org/10.1093/nar/16.3 .1215 .

Montaldo, H. H., and E. Manfredi. 2002. Organisation of selection programmes for dairy goats. No. 01-35 in 7th World Congr. Genet. Appl. Livest. Prod. Montpellier, France.

Mucha, S., R. Mrode, M. Coffey, M. Kizilaslan, S. Desire, and J. Conington. 2018. Genome-wide association study of conformation and milk yield in mixed-breed dairy goats. J. Dairy Sci. 101:2213-2225. https://doi.org/10.3168/jds.2017-12919.

N'Diaye, A., G. K. Chen, C. D. Palmer, B. Ge, B. Tayo, R. A. Mathias, J. Ding, M. A. Nalls, A. Adeyemo, V. Adoue, C. B. Ambrosone, L. Atwood, E. V. Bandera, L. C. Becker, S. I. Berndt, L. Bernstein, W. J. Blot, E. Boerwinkle, A. Britton, G. Casey, S. J. Chanock, E. Demerath, S. L. Deming, W. R. Diver, C. Fox, T. B. Harris, D. G. Hernandez, J. J. Hu, S. A. Ingles, E. M. John, C. Johnson, B. Keating, R. A. Kittles, L. N. Kolonel, S. B. Kritchevsky, L. Le Marchand, K. Lohman, J. Liu, R. C. Millikan, A. Murphy, S. Musani, C. Neslund-Dudas, K. E. North, S. Nyante, A. Ogunniyi, E. A. Ostrander, G. Papanicolaou, S. Patel, C. A. Pettaway, M. F. Press, S. Redline, J. L. Rodriguez-Gil, C. Rotimi, B. A. Rybicki, B. Salako, P. J. Schreiner, L. B. Signorello, A. B. Singleton, J. L. Stanford, A. H. Stram, D. O. Stram, S. S. Strom, B. Suktitipat, M. J. Thun, J. S. Witte, L. R. Yanek, R. G. Ziegler, W. Zheng, X. Zhu, J. M. Zmuda, A. B. Zonderman, M. K. Evans, Y. Liu, D. M. Becker, R. S. Cooper, T. Pastinen, B. E. Henderson, J. N. Hirschhorn, G. Lettre, and C. A. Haiman. 2011. Identification, replication, and fine-mapping of loci associated with adult height in individuals of African ancestry. PLoS Genet. 7:e1002298. https: //doi.org/10.1371/journal.pgen.1002298.

Nagata, K., S. Kiryu-Seo, H. Tamada, F. Okuyama-Uchimura, H. Kiyama, and T. C. Saido. 2016. ECEL1 mutation implicates impaired axonal arborization of motor nerves in the pathogenesis of distal arthrogryposis. Acta Neuropathol. 132:111-126. https://doi .org/10.1007/s00401-016-1554-0.

Oget, C., G. Tosser-Klopp, and R. Rupp. 2019. Genetic and genomic studies in ovine mastitis. Small Rumin. Res. 176:55-64. https:// doi.org/10.1016/j.smallrumres.2019.05.011.

Paradies, G., V. Paradies, V. De Benedictis, F. M. Ruggiero, and G. Petrosillo. 2014. Functional role of cardiolipin in mitochondrial bioenergetics. Biochim. Biophys. Acta 1837:408-417. https://doi .org/10.1016/j.bbabio.2013.10.006.

Pérez-Cabal, M. A., E. Legaz, I. Cervantes, L. F. de la Fuente, R. Martínez, F. Goyache, and J. P. Gutiérrez. 2013. Association between body and udder morphological traits and dairy performance in Spanish Assaf sheep. Arch. Tierzucht 56:430-442. https://doi.org/ 10.7482/0003-9438-56-042.

Pugh, D. G., and A. N. Baird. 2012. Sheep and Goat Medicine. 2nd ed. Elsevier, St. Louis, MO.

Qian, D., C. Jones, A. Rzadzinska, S. Mark, X. Zhang, K. P. Steel, X. Dai, and P. Chen. 2007. WNT5A functions in planar cell polarity regulation in mice. Dev. Biol. 306:121-133. https://doi.org/10 .1016/j.ydbio.2007.03.011.

R Core Team. 2017. R: A Language and environment for statistical computing. R Found. Stat. Comput., Vienna, Austria. http//www .R-project.org/.

Rogers, G. W., G. L. Hargrove, T. J. Lawlor Jr., and J. L. Ebersole. 1991. Correlations among linear type traits and somatic cell counts. J. Dairy Sci. 74:1087-1091. https://doi.org/10.3168/jds .S0022-0302(91)78259-3.

Rupp, R., and D. Boichard. 1999. Genetic parameters for clinical mastitis, somatic cell score, production, udder type traits, and milking ease in first lactation Holsteins. J. Dairy Sci. 82:2198-2204. https: //doi.org/10.3168/jds.S0022-0302(99)75465-2.

Rupp, R., and D. Boichard. 2003. Genetics of resistance to mastitis in dairy cattle. Vet. Res. 34:671-688. https://doi.org/10.1051/vetres: 2003020.

Rupp, R., V. Clément, A. Piacere, C. Robert-Granié, and E. Manfredi. 2011. Genetic parameters for milk somatic cell score and relationship with production and udder type traits in dairy Alpine and Saanen primiparous goats. J. Dairy Sci. 94:3629-3634. https://doi .org/10.3168/jds.2010-3694.

Rupp, R., P. Senin, J. Sarry, C. Allain, C. Tasca, L. Ligat, D. Portes, F. Woloszyn, O. Bouchez, G. Tabouret, M. Lebastard, C. Caubet, G. Foucras, and G. Tosser-Klopp. 2015. A point mutation in suppressor of cytokine signalling 2 (SOCS2) increases the susceptibility to inflammation of the mammary gland while associated with higher body weight and size and higher milk production in a sheep 
model. PLoS Genet. 11:e1005629. https://doi.org/10.1371/journal .pgen.1005629.

Sánchez-Rodríguez, M. 2012. Valoración morfológica del ganado caprino lechero. Juzgamiento y calificación. 2nd ed. Editorial Servet, Zaragoza, Spain.

Schmid, M., and J. Bennewitz. 2017. Invited review: Genome-wide association analysis for quantitative traits in livestock-A selective review of statistical models and experimental designs. Arch. Tierzucht 60:335-346. https://doi.org/10.5194/aab-60-335-2017.

Sevane, N., E. Armstrong, P. Wiener, R. Pong Wong, S. Dunner, V. Amarger, D. Delourme, H. Levéziel, S. Boitard, B. Mangin, J. Cañón, M. L. Checa, D. García, M. E. Miranda, R. Pérez, M. Christensen, P. Ertbjerg, A. Crisá, C. Marchitelli, A. Valentini, S. Failla, S. Gigli, J. F. Hocquette, G. Nute, I. Richardson, J. L. Olleta, B. Panea, C. Sañudo, N. Razzaq, G. Renand, and J. L. Williams. 2014. Polymorphisms in twelve candidate genes are associated with growth, muscle lipid profile and meat quality traits in eleven European cattle breeds. Mol. Biol. Rep. 41:4721-4731. https://doi.org/10.1007/s11033-014-3343-y.

Seykora, A. J., and B. T. McDaniel. 1985. Udder and teat morphology related to mastitis resistance: A review. J. Dairy Sci. 68:20872093. https://doi.org/10.3168/jds.S0022-0302(85)81072-9.

Shelton, M. 1978. Reproduction and breeding of goats. J. Dairy Sci. 61:994-1010. https://doi.org/10.3168/jds.S0022-0302(78)83680-7.

Shim, H., D. I. Chasman, J. D. Smith, S. Mora, P. M. Ridker, D. A. Nickerson, R. M. Krauss, and M. Stephens. 2015. A multivariate genome-wide association analysis of 10 LDL subfractions, and their response to statin treatment, in 1868 caucasians. PLoS One 10:e0120758. https://doi.org/10.1371/journal.pone.0120758.

Sutherland, K. D., G. J. Lindeman, and J. E. Visvader. 2007. Knocking off $S O C S$ genes in the mammary gland. Cell Cycle 6:799-803. https://doi.org/10.4161/cc.6.7.4037.

Thankam, F. G., I. S. Chandra, A. N. Kovilam, C. G. Diaz, B. T. Volberding, M. F. Dilisio, M. M. Radwan, R. M. Gross, and D. K. Agrawal. 2018. Amplification of mitochondrial activity in the healing response following rotator cuff tendon injury. Sci. Rep. 8:17027. https://doi.org/10.1038/s41598-018-35391-7.

UniProt Consortium. 2019. UniProt: A worldwide hub of protein knowledge. Nucleic Acids Res. 47(D1):D506-D515. https://doi .org/10.1093/nar/gky1049.

Wang, X., K. Harimoto, J. Liu, J. Guo, S. Hinshaw, Z. Chang, and Z. Wang. 2011. SPATA 4 promotes osteoblast differentiation through Erk-activated Runx2 pathway. J. Bone Miner. Res. 26:1964-1973. https://doi.org/10.1002/jbmr.394.
Yamaguchi, T. P., A. Bradley, A. P. McMahon, and S. Jones. 1999. A WNT5A pathway underlies outgrowth of multiple structures in the vertebrate embryo. Development 126:1211-1223.

Yang, J., B. Benyamin, B. P. McEvoy, S. Gordon, A. K. Henders, D. R. Nyholt, P. A. Madden, A. C. Heath, N. G. Martin, G. W. Montgomery, M. E. Goddard, and P. M. Visscher. 2010. Common SNPs explain a large proportion of the heritability for human height. Nat. Genet. 42:565-569. https://doi.org/10.1038/ng.608.

Yang, Y., J. Cao, and Y. Shi. 2004. Identification and characterization of a gene encoding human LPGAT1, an endoplasmic reticulumassociated lysophosphatidylglycerol acyltransferase. J. Biol. Chem. 279:55866-55874. https://doi.org/10.1074/jbc.M406710200.

Yildiz, A. 2018. Single-molecule dynein motor mechanics in vitro. Pages 113-135 in Dynein Mechanics, Dysfunction, and Disease. 2nd ed. S. M. King, ed. Academic Press, London, UK.

Zhou, H., D. F. Shen, Z. Y. Bian, J. Zong, W. Deng, Y. Zhang, Y. Y. Guo, H. Li, and Q. Z. Tang. 2011. Activating transcription factor 3 deficiency promotes cardiac hypertrophy, dysfunction, and fibrosis induced by pressure overload. PLoS One 6:e26744. https://doi .org/10.1371/journal.pone.0026744.

Zhou, X., and M. Stephens. 2012. Genome-wide efficient mixed-model analysis for association studies. Nat. Genet. 44:821-824. https:// doi.org/10.1038/ng.2310.

Zujovic, M., N. Memisi, V. Bogdanovic, and Z. Tomic. 2011. Correlation between body measurements and milk production of goats in different lactations. Biotechnol. Anim. Husb. 27:217-225. https:// doi.org/10.2298/BAH1102217Z.

\section{ORCIDS}

Maria Gracia Luigi-Sierra @ https://orcid.org/0000-0002-6414-0550 Vincenzo Landi @ https://orcid.org/0000-0003-1385-8439

Dailu Guan 은 https://orcid.org/0000-0001-8800-3158

Juan Vicente Delgado (ํ) https://orcid.org/0000-0003-1657-8838

Anna Castelló @ ㄴ https://orcid.org/0000-0001-8497-6251

Emilio Mármol-Sánchez @ \ttps://orcid.org/0000-0002-4393-1740

Javier Fernández Alvarez @ https://orcid.org/0000-0003-0450-5869

Mayra Gómez-Carpio @ https://orcid.org/0000-0002-3426-2231

Amparo Martínez @ https://orcid.org/0000-0002-6944-0501

Xavier Such ำ https://orcid.org/0000-0002-9712-4477

Jordi Jordana @ https://orcid.org/0000-0002-7789-2989

Marcel Amills @ https://orcid.org/0000-0002-8999-0770 